\title{
Phytoprotection
}

\section{Susceptibility of apples to damage by Lygocoris communis and Lygus lineolaris (Hemiptera : Miridae)}

\section{O.D. Michaud, R.K. Stewart et G. Boivin}

Volume 71, numéro 1, 1990

URI : https://id.erudit.org/iderudit/705979ar

DOI : https://doi.org/10.7202/705979ar

Aller au sommaire du numéro

Éditeur(s)

Société de protection des plantes du Québec (SPPQ)l

ISSN

0031-9511 (imprimé)

1710-1603 (numérique)

Découvrir la revue

Citer cet article

Michaud, O., Stewart, R. \& Boivin, G. (1990). Susceptibility of apples to damage by Lygocoris communis and Lygus lineolaris (Hemiptera : Miridae).

Phytoprotection, 71(1), 25-30. https://doi.org/10.7202/705979ar

\section{Résumé de l'article}

Les dommages causés par les larves et les adultes du Lygocoris communis et du Lygus lineolaris aux pommiers (cv. Mclntosh) ont été évalués au moyen de cages de mousseline placées sur des branches de pommiers. Chaque larve de $L$. communis placée en cage au calice a endommagé une moyenne de 2,1 pommes alors que chaque adulte placé en cage à la nouaison en a endommagé 2,0 . Les dommages causés par les jeunes larves $\left(1^{\mathrm{er}}, 2^{\mathrm{e}}\right.$ et $3^{\mathrm{e}}$ stades) ont été plus importants que ceux causés par les vieilles larves $\left(4^{\mathrm{e}}\right.$ et $5^{\mathrm{e}}$ stades) et les adultes. Chaque adulte hivernant de $L$. lineolaris a détruit une moyenne de 4,5 bourgeons à fruits. Chaque adulte de L. lineolaris a endommagé une moyenne de 4,0 pommes lorsque l'attaque avait lieu du stade du pré-bouton rose à la pleine floraison. 


\title{
Susceptibility of apples to damage by Lygocoris communis and Lygus lineolaris (Hemiptera: Miridae)
}

\author{
O. D. Michaud, R.K. Stewart \\ Department of Entomology, Macdonald College of McGill University, \\ 21111 Lakeshore Road, Sainte-Anne-de-Bellevue, Québec, Canada H9X 1CO
}

\author{
G. Boivin \\ Research Station, Agriculture Canada, P. O. Box 457, \\ Saint-Jean-sur-Richelieu, Québec, Canada J3B 6Z8. Contribution No. 335/89.13.R
}

(Received 1989-03-21; accepted 1989-10-29)

\begin{abstract}
Damage to apples (cv. McIntosh) caused by nymphs and adults of Lygocoris communis and Lygus lineolaris was evaluated by placing insects in sleeve-cages on apple-bearing branches. Each nymph of $L$. communis placed in the cage at petal fall damaged an average of 2.1 apples whereas each adult placed in the cage after fruit set damaged 2.0 apples. Damage by young nymphs $\left(1^{\text {st }}, 2^{\text {nd }}\right.$ and $3^{\text {rd }}$ instars $)$ was severe whereas damage caused by old nymphs $\left(4^{\text {th }}\right.$ and $5^{\text {th }}$ instars) and adults was light. Each overwintered adult of $L$. lineolaris damaged an average of 4.5 fruit clusters. Each adult damaged an average of 4.0 apples when they attacked from tight-cluster to full-bloom stage.
\end{abstract}

Michaud, O. D., R. K. Stewart, and G. Boivin. 1990. Susceptibility of apples to damage by Lygocoris communis and Lygus lineolaris (Hemiptera: Miridae). PHYTOPROTECTION 71 : 25-30.

Les dommages causés par les larves et les adultes du Lygocoris communis et du Lygus lineolaris aux pommiers (cv. McIntosh) ont été évalués au moyen de cages de mousseline placées sur des branches de pommiers. Chaque larve de $L$. communis placée en cage au calice a endommagé une moyenne de 2,1 pommes alors que chaque adulte placé en cage à la nouaison en a endommagé 2,0 . Les dommages causés par les jeunes larves $\left(1^{\mathrm{er}}, 2^{\mathrm{e}}\right.$ et $3^{\mathrm{e}}$ stades) ont été plus importants que ceux causés par les vieilles larves $\left(4^{\mathrm{e}}\right.$ et $5^{\mathrm{e}}$ stades $)$ et les adultes. Chaque adulte hivernant de $L$. lineolaris a détruit une moyenne de 4,5 bourgeons à fruits. Chaque adulte de $L$. lineolaris a endommagé une moyenne de 4,0 pommes lorsque l'attaque avait lieu du stade du pré-bouton rose à la pleine floraison.

\section{Introduction}

Phytophagous mirids are important pests of apples (Malus sylvestris Mill.) throughout northeastern North America (McMullen and Jong 1970; Parent et al. 1976; Rivard et al. 1980). The tarnished plant bug, Lygus lineolaris (Palisot de Beauvois), is now considered to be one of the key pests in Quebec apple orchards (Paradis 1981). However, Boivin et al. (1979) showed that the population densities of the green apple bug, Lygocoris communis (Knight), may be higher than those of $L$. lineolaris in unsprayed apple orchards.

The multivoltine L. lineolaris overwinters in the adult stage under the leaf litter (Khattat and Stewart 1980). These adults are responsible for apple bud damage early in spring (Prokopy et al. 1978, 1982). L. communis is a univoltine species, overwintering as eggs inserted beneath the bark of apple

$0031-9511 / 90 \$ 1.00+.10$ twigs (Brittain 1916). The young nymphs of this species attack the blossoms and young fruits of the apple trees, from full-bloom to fruit-set stages (Boivin and Stewart 1982).

Qualitative characteristics permitting the distinction between apple damage caused by L. lineolaris and L. communis punctures have been described by Boivin and Stewart (1982) but no quantitative evaluation was done. A basic requirement for the implementation of an integrated pest management program is to assess the need for and proper timing of pesticide treatments. Although in Quebec apple orchards both mirid species may be controlled by one or two insecticide sprays at pink stage and petal fall, L. lineolaris may damage $30 \%$ of apple buds in some orchards (Paradis 1983). This study was thus undertaken to evaluate the susceptibility of different apple phenological stages to injury by both mirid species. The attack potential of a single individual of each mirid species will also be discussed. The preference for or avoidance of certain apple cultivars by $L$. communis and $L$. lineolaris was also investigated. 


\section{Materials and methods}

The experiments were conducted from 1983 to 1985 in two orchards at the experimental farm of Agriculture Canada in Frelighsburg $\left(45^{\circ} 03^{\prime} \mathrm{N}, 72^{\circ} 50^{\prime} \mathrm{W}\right)$, Quebec. Orchard I contained 167 mature standard apple trees (90\% 'McIntosh', $10 \%$ 'Cortland' and 'Bancroft' cultivars) whereas orchard II contained 82 mature standard apple trees $(65 \%$ 'McIntosh' and $35 \%$ 'Melba', 'Cortland' and 'Fameuse' cultivars). Both orchards were kept under standard orchard management practices but were not sprayed with insecticides. All experiments were made in both orchards except for the evaluation of damage at harvest for different apple cultivars which was only done in orchard II.

The cages used were made of Tergal ${ }^{\circledR}(c a$ 35 threads $/ \mathrm{cm}$ ) and had a cylindrical shape, $100 \mathrm{~cm}$ long by $35 \mathrm{~cm}$ in diameter, each cage enclosing the apical $75 \mathrm{~cm}$ of one apple branch. Fifty sleeve-cages were installed randomly throughout the orchards on 'McIntosh' apple trees and were in place from early April to the end of October. Before caging, each apple branch was carefully examined to ensure that no insects or eggs were present. As reported by Boivin and Stewart (1982), all fruit clusters on the chosen limbs outside the cages were removed at the pink stage to provide a greater supply of nutrients and to reduce fruit drop of the remaining caged apple buds. Flowers inside the cages were pollinated by applying a mixture of two pollen varieties ('Cortland' and 'Vistabella') to the pistil of every blossom with a small brush.

All nymphs and adults used in these experiments were obtained by sampling in the same orchard. The sex of the adults was not determined. Variable numbers of replicates were used for each insect/apple ratio depending on the availability of fruit clusters. Each year, two non-infested cages were used as controls.

Lygocoris communis. Insect :apple ratios ranging from $1: 1$ to $1: 16$ were tested to determine the number of apples liable to be damaged by individuals of $L$. communis. These infestation levels were repeated separately for three different developmental stages of $L$. communis. The young nymphs
(L1, L2 and L3), represented in this experiment by the second-instar nymphs, were placed in the cages at petal fall, the older nymphs (L4 and L5), represented by the fourth-instar nymphs, were placed in the cages 3 days after fruit set and finally the adults were placed 4,11 , and 18 days after fruit set.

Ten cages were also infested 12 days after fruit set with third-instar nymphs of L. communis captured under the apple trees with a D-vac suction apparatus. This experiment was carried out in order to determine if these nymphs migrated from the trees to ground habitat because of a reduced attractiveness of apple trees.

The young nymphs were observed daily and removed from the cages the day of their third moult and the older nymphs as soon as they moulted to adults. L. communis adults were kept caged until their death. The emptied cages were always resealed until harvest time to prevent later infestations by insects. Infestations of caged branches with L. communis nymphs were carried out by means of a camel hair brush thus permitting the placement of nymphs and adults on a fruit cluster.

Visual observations of 50 naturally infested apples, 10 days after the fruit set, were also carried out in order to obtain more information on the feeding habit of L. communis adults.

Lygus lineolaris. Insect:apple ratios ranging from $1: 1$ to $1: 12$ were tested to determine the number of apples liable to be damaged by adult individuals of $L$. lineolaris. To determine the stage at which the developing apples are most susceptible to attack by overwintered $L$. lineolaris and to study the nature of the resulting damage, infestations with overwintered adults were made at four different periods of apple bud development (period $1=$ half-inch green to tight cluster; period 2 = tight cluster to full bloom; period 3 = beginning of fruit set; period $4=1$ month after fruit set).

Susceptibility of apple cultivars. Susceptibility of different cultivars to damage by $L$. communis and $L$. lineolaris was studied by examining 200 apples taken randomly from the ground and 300 apples picked from the trees for each apple cultivar present in 
orchard II at harvest time. Injury due to each mirid species was recorded separately but multiple punctures caused by the same species on a single fruit was considered as a single damage. The percentages of damage were considered significantly different when their confidence limits for a proportion were non-overlapping (Steel and Torrie 1980).

\section{Results and discussion}

As the control sleeve-cages showed no alteration to the apples (size, colour or shape), the damage observed inside infested cages was attributed to the insects purposely introduced. Leaves inside the control cages also developed normally except for those in direct contact with the tergal which curled back from the material. These sleeve-cages, already used by Boivin and Stewart (1982), provided good environmental conditions in which nymphal development was comparable to elsewhere in the orchard. Apple damage obtained inside sleeve-cages was similar to that observed on apples exposed to natural infestations outside the cage.

Lygocoris communis. The percentages of apples injured by $L$. communis young nymphs, old nymphs and adults are presented in Tables 1 and 2. In contrast to Boivin and Stewart (1982), who indicated that only the young nymphs were responsible for apple damage, the cage experiments showed that old nymphs, and sometimes adults may injure apples. The proportional decrease of percentages of apple damage with nymph:apples ratio indicates that individual nymphs restrict themselves to an average of 1.5 apples (Table 1). The higher number of apples damaged by a single individual ( $c a 2.6$ apples by young nymphs and $c a 1.9$ apples by old nymphs) in the cages enclosing either 8 or 16 apples was probably because of the clustered distribution of apples in the cages. The apples injured inside these cages were always those of the cluster on which we actually placed the nymphs. This indicates a low mobility of L. communis nymphs.

Artificial infestations with young or old nymphs resulted in damage reaching $100 \%$ with a ratio of 1 insect: 1 apple (Table 1). Fruits damaged by young nymphs were badly deformed at harvest whereas injuries due to old nymphs resulted in scars or depressions of lesser importance.

The 10 cages infested 12 days after fruit set with third-instar nymphs of $L$. communis taken from the ground showed no sign of punctures on apples at harvest. The apple surface was then probably too hard at this period to allow the insertion of nymphal mouthparts. This would explain the possible nymph migration to ground vegetation for more suitable food. Boivin and Stewart (1983b) suggested that the few nymphs

Table 1. Damage to 'McIntosh' apples due to the feeding of Lygocoris communis nymphs at various infestation levels in 1983-1985

\begin{tabular}{lccc}
\hline $\begin{array}{l}\text { Nymph:apples } \\
\text { ratio }\end{array}$ & $\begin{array}{c}\text { Total number } \\
\text { of replicates }\end{array}$ & $\begin{array}{c}\text { Number of damaged } \\
\text { apples per cage } \\
(\bar{x} \pm \text { S.D. })\end{array}$ & $\begin{array}{c}\text { Damaged } \\
\text { apples } \\
(\% \pm \text { C.I. })\end{array}$ \\
\hline Young nymphs & 3 & $1.0 \pm 0.0$ & 100.0 \\
$1: 1$ & 8 & $1.5 \pm 0.5$ & $75.0 \pm 21.2$ \\
$1: 2$ & 7 & $1.4 \pm 0.5$ & $35.7 \pm 17.7$ \\
$1: 4$ & 7 & $2.4 \pm 0.9$ & $30.4 \pm 12.0$ \\
$1: 8$ & 5 & $2.8 \pm 0.8$ & $17.5 \pm 8.3$ \\
$1: 16$ & & & \\
Old nymphs & 9 & $1.0 \pm 0.0$ & 100.0 \\
$1: 1$ & 12 & $1.1 \pm 0.7$ & $56.7 \pm 19.7$ \\
$1: 2$ & 14 & $1.2 \pm 0.5$ & $36.7 \pm 12.5$ \\
$1: 4$ & 7 & $1.7 \pm 0.5$ & $21.3 \pm 11.3$ \\
$1: 6$ & 7 & $2.0 \pm 0.0$ & $12.5 \pm 11.5$ \\
$1: 8$ & 2 & & \\
$1: 16$ & & 0.5 & \\
\hline
\end{tabular}

$\S$ S. D. = Standard deviation.

$\dagger$ C. I. = Confidence interval at $95 \%$. 
Table 2. Damage to 'McIntosh' apples due to the feeding of Lygocoris communis adults at various infestation levels in 1983-1985

\begin{tabular}{lcccc}
\hline $\begin{array}{l}\text { Time of artificial } \\
\text { infestation } \\
\text { (days after fruit set) }\end{array}$ & $\begin{array}{c}\text { Adult:apples } \\
\text { ratio }\end{array}$ & $\begin{array}{c}\text { Total number } \\
\text { of replicates }\end{array}$ & $\begin{array}{c}\text { Number of damaged } \\
\text { apples per cage } \\
(\bar{x} \pm \text { S.D. }) \&\end{array}$ & $\begin{array}{c}\text { Damaged } \\
\text { apples } \\
(\% \pm \text { C.I. }) \dagger\end{array}$ \\
\hline 4 & $1: 1$ & 5 & $0.4 \pm 0.5$ & $4.0 .0 \pm 35.1$ \\
& $1: 2$ & 3 & $1.0 \pm 0.0$ & $50.0 \pm 40.0$ \\
& $1: 4$ & 5 & $1.0 \pm 0.0$ & $25.0 \pm 19.0$ \\
& $1: 6$ & 2 & $1.0 \pm 0.0$ & $16.7 \pm 21.1$ \\
& $1: 8$ & 3 & $1.7 \pm 0.6$ & $20.8 \pm 16.2$ \\
11 & $1: 16$ & 1 & 2.0 & $16.7 \pm 18.3$ \\
& $1: 1$ & 4 & 0 & 0 \\
& $1: 2$ & 4 & 0 & 0 \\
18 & $1: 4$ & 5 & 0 & 0 \\
& $1: 8$ & 3 & 0 & 0 \\
& $1: 1$ & 5 & 0 & 0 \\
& $1: 2$ & 5 & 0 & $5.0 \pm 9.6$ \\
& $1: 4$ & 5 & $0.2 \pm 0.4$ & $3.5 \pm 4.8$ \\
& $1: 8$ & 5 & $0.2 \pm 0.4$ & $3.1 \pm 6.0$ \\
\hline
\end{tabular}

§ S. D. = Standard deviation.

$\dagger$ C. I. = Confidence interval at $95 \%$.

found on ground vegetation probably came from apple branches and have a longer development on weeds than on apple trees.

Infestations of apples with $L$. communis adults 4 days after fruit set resulted in damage at harvest (Table 2). The presence of $L$. communis adults in the cages 4 days after fruit set, resulted in damage varying from $16.7 \%$ to $50.0 \%$ of the caged fruits, indicating an attack potential of no more than two apples per adult, and was characterized by light depressions on mature apples. However, when infestations occurred 11 days after fruit set, the apple skin was tougher and $L$. communis adults were probably not able to introduce their stylets through it.

The few cases of damaged apples resulting from infestations of $L$. communis adults
18 days after fruit set are probably due to the fact that, in 1985, the apples were smaller and softer $(1.5 \mathrm{~cm}$ in diameter $)$ compared to those in 1983 ( $2 \mathrm{~cm}$ in diameter) at the time of artificial infestation.

Visual observations, 10 days after fruit set, of 50 apples naturally infested by $L$. communis adults showed that $94 \%$ of those adults $(\mathrm{N}=50)$ were in fact puncturing inside old wounds made earlier by the plum curculio, Conotrachelus nenuphar (Herbst), or by other phytophagous mirids.

Lygus lineolaris. The percentages of fruit clusters injured by $L$. lineolaris adults between the half-inch-green and tightcluster stages for different ratios of insect:fruit clusters are presented in Table 3. Since the apple stems were not separated,

Table 3. Damage to 'McIntosh' fruit clusters due to the feeding of Lygus lineolaris adults at various infestation levels between the half-inch-green and tight-cluster stages of the apple bud phenology

\begin{tabular}{lccr}
\hline $\begin{array}{l}\text { Insect: } \\
\text { fruit cluster } \\
\text { ratio }\end{array}$ & $\begin{array}{c}\text { Total number } \\
\text { of replicates }\end{array}$ & $\begin{array}{c}\text { Number of damaged } \\
\text { fruit clusters per cage } \\
(\bar{x} \pm \text { S.D. }) \S\end{array}$ & $\begin{array}{c}\text { Damaged fruit } \\
\text { clusters } \\
(\% \pm \text { C.I. }) \dagger\end{array}$ \\
\hline $1: 1$ & 2 & $1.0 \pm 0.0$ & 100.0 \\
$1: 3$ & 3 & $1.7 \pm 0.6$ & $55.5 \pm 32.5$ \\
$1: 5$ & 2 & $2.5 \pm 0.7$ & $50.0 \pm 31.0$ \\
$1: 7$ & 5 & $4.2 \pm 0.5$ & $60.0 \pm 16.2$ \\
$1: 9$ & 4 & $4.5 \pm 0.6$ & $50.0 \pm 16.3$ \\
$1: 11$ & 2 & $4.5 \pm 0.7$ & $40.9 \pm 20.5$ \\
\hline
\end{tabular}

$\S$ S. D. = Standard deviation.

$\dagger$ C. I. = Confidence interval at $95 \%$. 
Table 4. Damage to 'McIntosh' apples due to the feeding of Lygus lineolaris adults at various infestation levels for different apple bud stages

\begin{tabular}{lcccc}
\hline $\begin{array}{l}\text { Time of } \\
\text { artificial } \\
\text { infestation }\end{array}$ & $\begin{array}{c}\text { Adult:apples } \\
\text { ratio }\end{array}$ & $\begin{array}{c}\text { Total number } \\
\text { of replicates }\end{array}$ & $\begin{array}{c}\text { Number of damaged } \\
\text { apples per cage } \\
(\bar{x} \pm \text { S.D. })\end{array}$ & $\begin{array}{c}\text { Damaged } \\
\text { apples } \\
+\%+\text { C. I. } \dagger\end{array}$ \\
\hline $\begin{array}{l}\text { Tight-cluster to } \\
\text { full-bloom stages }\end{array}$ & $1: 1$ & 5 & $1.0 \pm 0.0$ & 100.0 \\
& $1: 2$ & 7 & $2.0 \pm 0.0$ & 100.0 \\
& $1: 4$ & 4 & $3.5 \pm 0.6$ & $87.5 \pm 16.2$ \\
& $1: 8$ & 5 & $4.0 \pm 0.7$ & $50.0 \pm 15.5$ \\
Fruit-set stage & $1: 12$ & 4 & $4.0 \pm 0.8$ & $33.3 \pm 13.3$ \\
& $1: 1$ & 5 & $1.0 \pm 0.0$ & 100.0 \\
& $1: 2$ & 5 & $1.4 \pm 0.5$ & $70.0 \pm 28.4$ \\
& $1: 4$ & 5 & $1.0 \pm 0.7$ & $25.0 \pm 19.0$ \\
One month after & $1: 6$ & 7 & $1.8 \pm 0.9$ & $26.2 \pm 13.3$ \\
fruit set & $1: 8$ & 4 & $1.0 \pm 0.8$ & $12.5 \pm 10.2$ \\
& $1: 1$ & 4 & 0 & 0 \\
& $1: 2$ & 4 & 0 & 0 \\
\end{tabular}

$\S$ S. D. = Standard deviation.

$\dagger$ C. I. = Confidence interval at $95 \%$.

flower buds were considered in clusters. Because most of the fruit clusters attacked before pollination desiccated and abscised, the damage indicated in Table 3 represents the damage evaluated 7 days after infestation. Even in the presence of several fruit clusters, an overwintering adult has the capability of attacking a maximum of 4.5 fruit clusters. According to Prokopy and Hubbell (1981), the attacks on flower buds by $L$. lineolaris adults prior to the tightcluster stage cause insufficient amount of bud abscission to affect yield since only $\mathrm{ca}$ 3 to $5 \%$ of the flowers present at the fullbloom stage are necessary for a full crop production at harvest. When the artificial infestations were performed from tightcluster to full-bloom stage, a higher percentage of damaged apples were recorded than those at the same infestation levels at fruit set (Table 4). The damage caused by a single individual from tight-cluster to full-bloom stage reached four apples per cage whereas after this period it averaged only one apple per cage.

Even though $L$. lineolaris adults have the potential to feed on the young developing apples at fruit set, they generally prefer ground vegetation (Boivin and Stewart 1983a). Experimental cages with adults of the first generation, captured at the beginning of July on apple branches and placed in the cages 1 month after fruit set, showed that these insects do not damage the apples (Table 4).

Susceptibility of apple cultivars. The 'Fameuse' cultivar was significantly more susceptible $(P \leq 0.05)$ to $L$. communis attack than was the 'Melba' (Table 5). However, no significant differences were found between the other cultivars. Brittain (1917) reported that some apple cultivars such as the 'Roxbury Russet' are more susceptible to be attacked by $L$. communis.

The 'Melba' cultivar was more susceptible to $L$. lineolaris attack than were the 5). Prokopy and Hubbell (1981) also men'McIntosh' and 'Cortland' cultivars (Table tioned that 'McIntosh' is significantly more susceptible to L. lineolaris deformation than 'Red Delicious'. Hammer (1939) noted that

Table 5. Percentage of damage due to Lygocoris communis and Lygus lineolaris feeding on different apple cultivars at Frelighsburg, Quebec, in 1984-1985

\begin{tabular}{llc}
\hline \multirow{2}{*}{$\begin{array}{l}\text { Apple } \\
\text { cultivar }\end{array}$} & \multicolumn{2}{c}{ Mean apple damage (\%) $\S$} \\
\cline { 2 - 3 } & $\begin{array}{l}\text { Lygocoris } \\
\text { communis }\end{array}$ & $\begin{array}{c}\text { Lygus } \\
\text { lineolaris }\end{array}$ \\
\hline Cortland & $1.90 \pm 0.85 \dagger$ & $3.20 \pm 1.09$ \\
Fameuse & $2.70 \pm 1.02$ & $4.40 \pm 1.27$ \\
Melba & $1.00 \pm 0.62$ & $6.90 \pm 1.57$ \\
McIntosh & $1.60 \pm 0.78$ & $3.00 \pm 1.06$ \\
\hline
\end{tabular}

$\S \mathrm{N}=500$.

$\dagger$ C. I. = Confidence interval at $95 \%$. 
apple cultivars react differently to $L$. lineolaris oviposition wounds; 'Red Delicious', 'Cortland' and 'Ben Davis' cultivars were the most susceptible whereas 'Duchess', 'Greening' and 'Baldwin' cultivars presented depressions of less importance.

The results of this study suggest that control measures against $L$. communis in orchards should be initiated against the young nymphs at petal fall as they are responsible for most of apple damage. On the other hand, for L. lineolaris, control measures should be applied at pink stage when feeding attacks by $L$. lineolaris are more likely to cause apple injury.

This research was funded by the Natural Sciences and Engineering Research Council of Canada and by the Conseil des Recherches en Pêches et Agroalimentaire du Québec.

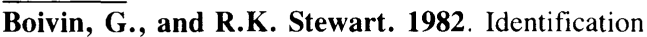
and evaluation of damage to McIntosh apples by phytophagous mirids (Hemiptera: Miridae) in southwestern Quebec. Can. Entomol. 114: 1037-1045.

Boivin, G., and R.K. Stewart. 1983a. Sampling technique and seasonal development of phytophagous mirids (Hemiptera: Miridae) on apple in Southwestern Quebec. Ann. Entomol. Soc. Am. 76: 359-364.

Boivin, G., and R.K. Stewart. 1983b. Seasonal development and interplant movements of phytophagous mirids (Hemiptera: Miridae) on alternate host plants in and around an apple orchard. Ann. Entomol. Soc. Am. 76: 776-780.

Boivin, G., R.K. Stewart, G. Mailloux, I. Rivard, and R.O. Paradis. 1979. Observations sur la punaise de la pomme Lygocoris communis (Knight) (Hemiptera: Miridae). Phytoprotection 60: 119-124.
Brittain, W.H. 1916. The green apple bug (Lygus invitus Say) in Nova Scotia. Entomol. Soc. Ont. Annu. Rep. 46: 65-78.

Brittain, W.H. 1917. The green apple bug in Nova Scotia. N. S. Dep. Agric. Bull. 8: 1-56.

Hammer, O.H. 1939. The tarnished plant bug as an apple pest. J. Econ. Entomol. 32: 259-264.

Khattat, R.R., and R.K. Stewart. 1980. Population fluctuations and interplant movements of Lygus lineolaris. Ann. Entomol. Soc. Am. 73: 282-287.

McMullen, R.D., and C. Jong. 1970. The biology and influence of pesticides on Campylomma verbasci (Heteroptera: Miridae). Can. Entomol. 102: 1390-1394.

Paradis, R.O. 1981. Lutte rationnelle contre les ravageurs des pommiers au Québec. Agric. Can. Res. St-Jean (Québec) Bull. Tech. 16, 32 pp.

Paradis, R.O. 1983. Lutte rationnelle contre les ravageurs des pommiers au Québec. Agric. Can. Res. St-Jean (Québec) Bull. Tech. 16, Ed. Rev., $51 \mathrm{pp}$.

Parent, B., R.O. Paradis, I. Rivard, and M. Mailloux. 1976. Les ravageurs des cultures fruitières dans le sud-ouest du Québec en 1975. Ann. Soc. Entomol. Qué. 21: 72-74.

Prokopy, R.J., and G.L. Hubbell. 1981. Susceptibility of apple to injury by tarnished plant bug adults. Environ. Entomol. 10: 977-979.

Prokopy, R.J., K.I. Hauschild, and R.G. Adams. 1978. Tarnished plant bug on apple: damage and monitoring traps. Fruit Notes 43: 10-14.

Prokopy, R.J., G.L. Hubbell, R.G. Adams, and K.I. Hauschild. 1982. Visual monitoring trap for tarnished plant bug adult on apple. Environ. Entomol. 11: 200-203.

Rivard, I., R.O. Paradis, and M. Mailloux. 1980. Les ravageurs des cultures fruitières du Québec en 1979. Ann. Soc. Entomol. Qué. 25: 77-80.

Steel, R. G. D., and J. H. Torrie. 1980. Principles and procedures of statistics. $2^{\text {nd }}$ ed. McGraw-Hill Inc., New York. 633 pp. 